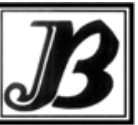

J. bio-sci. 17: 51-55, 2009

ISSN 1023-8654

http://www.banglajol.info/index.php/JBS/index

\title{
INPLUENCE OF GROWTH REGULATORS ON ROOT AND SHOOT CHARACTERS OF ONION
}

\author{
M MUd-Deen ${ }^{*}$, G Kabir \\ Department of Botany, University of Rajshahi, Rajshahi-6205, Bangladesh \\ ${ }^{1}$ Department of Crop Science \& Technology, University of Rajshahi, Rajshahi-6205,
}

\begin{abstract}
Context: The growth behaviour and yield of any crop plants are governed by their genetic potential, climatic conditions and the supply of nutrients. Specific control of these processes can be done by the application of plant bioregulators of natural or synthetic origin.

Objectives: The aim of the present investigation was to study the effect of different plant growth regulators on root and shoot emergence, and root and shoot length of onion.

Materials and Methods: Onion. var "Taherpuri" was used as plant material and four growth regulators namely $\mathrm{GA}_{3}$, Uniconazol, CCC and 2,3,6-TBA along with water as control with different concentration viz. 100, 150, 200, 250 and 300 ppm were used as treatment. Onion bulbs were placed on vials containing different doses of growth regulators. Data recorded on root and shoot emergence and their lengths after different days of setting the experiment.
\end{abstract}

Results: Higher concentrations of uniconazole necessitated maximum days for root and shoot emergence whereas $\mathrm{GA}_{3}$ required minimum days. Root length decreased gradually with increasing the concentrations of all the growth regulators at different days of emergence. Higher concentrations of $\mathrm{GA}_{3}$ produced longest shoot whereas same concentrations of uniconazole produced the shortest than the lower ones at different days of emergence. The highly significant and negative correlation was found between days to root emergence and shoot length and between days to shoot emergence and shoot length but highly significant and positive correlation was found between root length and shoot length.

Conclusion: $\mathrm{GA}_{3}$ required minimum days to root and shoot emergence and promote the vegetative growth of onion whereas uniconazole and CCC are retards and 2,3,6-TBA shows a little retarding effect.

Key words: Growth regulators, Root and shoot characters, Onion

\section{Introduction}

Onion (Allium cepa L.) is cultivated in Bangladesh through bulbs and seedlings. Bulbs are sown in early rabi season both for seeds and commercial purpose (Ud-Deen et al. 1997, 2005). Germination is the first consideration of plant set in the field but seedling emergence is the first step for proper growth and development of plant. The growth behavior and yield formation of crop plants are governed by their genetic potential, climatic conditions and the supply of nutrients. Specific control of these processes by the application of plant bioregulators of natural or synthetic origin is increasingly emerging in recent years. Growth retardants are diverse groups of chemicals, which have the common physiological effect of reducing stem growth by inhibiting cell division of the subapical meristem. $\mathrm{GA}_{3}$ is one of growth stimulating hormone whereas uniconazole and CCC are growth retardants, which belongs to a group of triazoles. 2,3,6-TBA is a hormone herbicide which shows a little retarding effect. Gibberellin is such as a compound that has a gibbane skeleton and that stimulates cell division or cell elongation or both (Paleg 1965). Gibberellin can cause a striking increase in shoot elongation in many plant species that is especially marked when certain

* Corresponding author: muddeen05@yahoo.com 
dwarf mutants are treated. Gibberellin can increase number of dividing cell and cell size in internodes that caused stem elongation but it retards rooting. It has positive effect on seed germination (Weaver 1981). Plant growth retardants retard cell division and cell elongation in shoot tissues by inhibiting gibberellin biosynthesis and thus, regulate plant height physiologically without causing malformation of leaves and stems. Henry (1985) reported that uniconazole reduced plant height by inhibiting GA biosynthesis. Coolbaugh and Hamilton (1976) reported that ancymidol (a growth retardant) also inhibits gibberellin biosynthesis. The present investigation was, therefore, undertaken to study the effect of different plant growth regulators on root and shoot emergence, and root and shoot length of onion.

\section{Materials and Methods}

The experiment was conducted in Professor Sultanul Alam Cytogenetics Laboratory, Department of Botany, University of Rajshahi using a promising local variety, "Taherpuri" (indigenous). The experiment was set up with two (02) factors (growth regulator and dose) Randomized Complete Block Design (RCBD) with three replications. The growth regulators were $\mathrm{GA}_{3}$ (Gibberellic acid/Gibberellin), Uniconazol (Sumiseven), CCC (Chlorocholine chloride or Cycocel) and 2,3,6-TBA (2,3,6-trichlorobenzoic acid) along with water as control. Among the four different growth regulators, $\mathrm{GA}_{3}$ is one of growth stimulating hormone whereas uniconazole and CCC are growth retardant and 2,3,6-TBA is a hormone herbicide and shows retarding effect. The doses were 100, 150, 200, 250 and $300 \mathrm{ppm}$ of each growth regulators. Onion bulbs were placed on vials containing water (control), GA3, uniconazole, CCC and 2,3,6 - TBA each with 100, 150, 200, 250 and 300 $\mathrm{ppm}$, except water. Data on four quantitative characters were recorded from randomly selected five different bulbs from each treatment after 5, 7 and 10 days of setting the experiment. Data recorded on root and shoot emergence and their lengths after different days of setting the experiment were termed as DAE.

The findings obtained from the experiment were analyzed statistically following MSTAT-C package program. The mean values recorded against all the treatments were compared by Duncun's Multiple Range Test (DMRT) and also with the help of LSD values following Gomez and Gomez (1984). A correlation study was made among these characters statistically.

\section{Results and Discussion}

Growth regulators used following different doses caused significant variation in respect of days to root and shoot emergence and their lengths (Table 1). In the present investigation, it was observed that onion bulbs treated with $300 \mathrm{ppm}$ uniconazole required maximum days $(8.00)$ for root emergence which was significantly different from that of all other treatments except uniconazole with $250 \mathrm{ppm}$ treated bulbs, when compared to control (water). On the other hand, bulbs treated with water, $100 \mathrm{ppm}$ and $150 \mathrm{ppm}$ of $\mathrm{GA}_{3}$ and all the doses of 2,3,6-TBA required the minimum day (1.00) for root emergence which were also significantly different from all other treatments.

In case of days to shoot emergence, it was found that bulbs treated with $300 \mathrm{ppm}$ uniconazole required maximum days (15.00) for shoot emergence (Table 1 ) which was significantly different form that of all other treatments. But the bulbs treated with $300 \mathrm{ppm} \mathrm{GA} 3$ required minimum days (5.00) for shoot emergence which was statistically similar with the bulbs treated with 200 ppm and 250 ppm GA 3 and the control plants.

Among the three different growth retardants uniconazole necessitated maximum days for root and shoot emergence followed by CCC and 2,3,6-TBA. But GA $\mathrm{A}_{3}$ showed very early response compared to retardant and water (Table 1). The table also reveals that among the five different doses, the highest dose (300 ppm) always necessitated maximum days for root emergence whereas the lowest dose $(100 \mathrm{ppm})$ of all the growth regulators necessitated minimum days except 2,3,6-TBA. In case of shoot emergence, higher dose (300 ppm) of uniconazole and CCC necessitated maximum days than lower ones (Table 1). But in case of $\mathrm{GA}_{3}$ higher dose necessitated minimum days and lower dose necessitated maximum days for shoot emergence. In case of 2,3,6-TBA all the doses responded equally with water for shoot emergence. 
These findings agreed well with the findings of Thomas (1968) who reported that malic hydrazide (MH) completely inhibited root and sprout development but the growth retardant CCC was mainly effective in reducing root development and sprouting was only slightly inhibited. Corgan (1974) also noted that ethephon application of 2500 to $5000 \mathrm{ppm}$ to onions strongly promoted bulbing and inhibited top and root growth, even during short photoperiods. Rahim and Alamgir (1995) reported that $\mathrm{GA}_{3}$ inhibited root growth in Colocasia esculenta.

Root length varied significantly among the treatments both at 5,7 and 10 days after emergence (DAE). From Table 1 it was observed that at 5,7 and 10 days after emergence the longest roots $(7.50 \mathrm{~cm}, 9.30 \mathrm{~cm}$ and $11.10 \mathrm{~cm}$ ) were produced by control bulbs (water treated) whereas $300 \mathrm{ppm}$ uniconazole treated bulbs produced the shortest ones $(1.50 \mathrm{~cm}, 3.20 \mathrm{~cm}$ and $5.00 \mathrm{~cm})$. It also reveals from the table that water treated bulbs produced longest root whereas uniconazole treated bulbs produced shortest root followed by CCC, $\mathrm{GA}_{3}$ and 2,3,6-TBA after 5, 7 and 10 days of emergence. It was also found that all the growth retardants reduced root length and uniconazole was found to be more effective. Table 1 shows that root length decreased gradually with increasing the concentrations of uniconazole, CCC, GA 3 and 2,3,6-TBA after 5, 7 and 10 days of emerging the root and when compared to that of control. Among the five different doses, higher dose (300 ppm) of uniconazole produced the shortest root followed by CCC, GA 3 and 2,3,6-TBA compared to that of control at 5th, 7th and 10th days of emergence. In case of 2,3,6-TBA the growth rate was very slow compared to that of other growth regulators.

Table 1 Effect of growth regulators along with control on days to root and shoot emergence, and root and shoot length of onion.

\begin{tabular}{|c|c|c|c|c|c|c|c|c|c|}
\hline \multirow{2}{*}{$\begin{array}{l}\text { Treat- } \\
\text { ments }\end{array}$} & \multirow{2}{*}{$\begin{array}{l}\text { Dose } \\
\text { (ppm) }\end{array}$} & \multirow{2}{*}{$\begin{array}{l}\text { Days to root } \\
\text { emergence }\end{array}$} & \multirow{2}{*}{$\begin{array}{l}\text { Days to shoot } \\
\text { emergence }\end{array}$} & \multicolumn{3}{|c|}{ Root length (cm) } & \multicolumn{3}{|c|}{ Shoot length (cm) } \\
\hline & & & & $5 \mathrm{DAE}$ & $7 \mathrm{DAE}$ & $10 \mathrm{DAE}$ & $5 \mathrm{DAE}$ & $7 \mathrm{DAE}$ & $10 \mathrm{DAE}$ \\
\hline Water & - & $1.00 f$ & $6.00 f g$ & $7.50 \mathrm{a}$ & $9.30 \mathrm{a}$ & $11.10 \mathrm{a}$ & $9.33 c-e$ & $14.00 \mathrm{~d}$ & $20.00 d$ \\
\hline \multirow{6}{*}{$\mathbb{0}_{0}^{\circ}$} & 100 & $1.00 f$ & 7.00ef & $5.50 \mathrm{~b}-\mathrm{e}$ & 6.50c-e & 7.50d-h & $10.50 \mathrm{~cd}$ & $16.00 \mathrm{c}$ & $22.00 \mathrm{c}$ \\
\hline & 150 & $1.00 f$ & 7.00ef & $5.50 \mathrm{~b}-\mathrm{e}$ & $6.50 c-e$ & 7.40d-h & $12.00 \mathrm{bc}$ & $16.50 \mathrm{c}$ & $22.50 \mathrm{c}$ \\
\hline & 200 & $3.00 \mathrm{e}$ & $6.00 \mathrm{fg}$ & 5.00c-e & $6.00 c-f$ & $7.00 \mathrm{e}-\mathrm{h}$ & $12.00 \mathrm{bc}$ & $17.00 \mathrm{c}$ & $24.00 \mathrm{~b}$ \\
\hline & 250 & $3.00 \mathrm{e}$ & $6.00 \mathrm{fg}$ & 5.00c-e & $6.00 c-f$ & $7.00 \mathrm{e}-\mathrm{h}$ & $14.00 \mathrm{ab}$ & $19.00 \mathrm{~b}$ & $24.00 \mathrm{~b}$ \\
\hline & 300 & $5.00 \mathrm{~cd}$ & $5.00 \mathrm{~g}$ & 4.50d-f & $5.70 d-f$ & 7.00e-h & $16.00 \mathrm{a}$ & $21.00 \mathrm{a}$ & $27.00 \mathrm{a}$ \\
\hline & Mean & 2.60 & 6.20 & 5.10 & 6.14 & 7.18 & 12.90 & 17.90 & 23.90 \\
\hline \multirow{6}{*}{$\begin{array}{l}\frac{0}{0} \\
\frac{1}{0} \\
\frac{8}{5} \\
\frac{0}{5}\end{array}$} & 100 & 4.00de & 7.00ef & $3.80 \mathrm{e}-\mathrm{g}$ & 5.90d-f & $8.20 c-f$ & 9.00d-f & 11.00ef & 16.00ef \\
\hline & 150 & $4.00 \mathrm{de}$ & $9.00 \mathrm{~cd}$ & $3.00 f-h$ & $5.00 e-g$ & $7.30 \mathrm{e}-\mathrm{h}$ & $9.00 \mathrm{~d}-\mathrm{f}$ & 11.00ef & 16.00ef \\
\hline & 200 & $6.00 \mathrm{bc}$ & $10.00 \mathrm{c}$ & $2.90 f-h$ & 4.50f-h & 6.90f-h & 8.00d-h & $10.00 f$ & $14.50 \mathrm{~g}$ \\
\hline & 250 & 7.00ab & $10.00 \mathrm{c}$ & $2.20 \mathrm{gh}$ & $3.90 \mathrm{gh}$ & $6.40 \mathrm{gh}$ & $6.50 \mathrm{gh}$ & $8.50 \mathrm{~g}$ & $12.50 \mathrm{~h}$ \\
\hline & 300 & $8.00 \mathrm{a}$ & $15.00 \mathrm{a}$ & $1.50 \mathrm{~h}$ & $3.20 \mathrm{~h}$ & $5.00 \mathrm{i}$ & $4.00 \mathrm{i}$ & $6.00 \mathrm{~h}$ & $10.00 \mathrm{i}$ \\
\hline & Mean & 5.80 & 10.20 & 2.68 & 4.50 & 6.76 & 7.30 & 9.30 & 13.80 \\
\hline \multirow{6}{*}{8} & 100 & $3.00 \mathrm{e}$ & $7.00 \mathrm{ef}$ & $4.90 c-e$ & $5.50 \mathrm{~d}-\mathrm{f}$ & $7.00 \mathrm{e}-\mathrm{h}$ & 9.50de & $11.50 \mathrm{e}$ & $17.00 \mathrm{e}$ \\
\hline & 150 & $3.00 \mathrm{e}$ & 7.00ef & 4.90c-e & $5.30 \mathrm{e}-\mathrm{g}$ & 7.0e-h & $9.50 \mathrm{de}$ & $11.00 \mathrm{ef}$ & $17.00 \mathrm{e}$ \\
\hline & 200 & $4.00 \mathrm{de}$ & $8.00 \mathrm{de}$ & 4.00ef & $5.00 e-g$ & $6.80 f-h$ & $8.50 \mathrm{~d}-\mathrm{g}$ & $10.00 f$ & 16.00ef \\
\hline & 250 & $5.00 \mathrm{~cd}$ & $9.00 \mathrm{~cd}$ & $4.00 \mathrm{ef}$ & $4.90 \mathrm{fg}$ & $6.80 f-h$ & $7.90 \mathrm{e}-\mathrm{h}$ & 10.50ef & $15.00 \mathrm{fg}$ \\
\hline & 300 & $6.00 \mathrm{bc}$ & $12.00 \mathrm{~b}$ & $3.00 f-h$ & $4.50 f-h$ & $6.20 \mathrm{hi}$ & $6.00 \mathrm{hi}$ & $8.00 \mathrm{~g}$ & $13.00 \mathrm{~h}$ \\
\hline & Mean & 4.20 & 8.60 & 4.16 & 5.04 & 6.76 & 8.28 & 10.20 & 15.60 \\
\hline \multirow{6}{*}{ 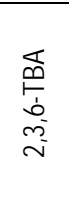 } & 100 & $1.00 f$ & 7.00ef & $6.90 \mathrm{ab}$ & $8.50 a b$ & 10.00ab & $10.00 c-e$ & 13.50d & $20.00 d$ \\
\hline & 150 & $1.00 f$ & 7.00ef & $6.50 \mathrm{a}-\mathrm{c}$ & $7.50 \mathrm{bc}$ & $9.10 \mathrm{bc}$ & 10.00c-e & 13.50d & $20.00 d$ \\
\hline & 200 & $1.00 f$ & 7.00ef & $6.00 \mathrm{a}-\mathrm{d}$ & $7.00 \mathrm{~cd}$ & $8.90 \mathrm{~b}-\mathrm{d}$ & 10.00c-e & 13.50d & 19.50d \\
\hline & 250 & $1.00 f$ & 7.00ef & $5.80 \mathrm{~b}-\mathrm{d}$ & $6.90 \mathrm{~cd}$ & 8.50c-e & $10.00 c-e$ & $13.00 \mathrm{~d}$ & 19.50d \\
\hline & 300 & $1.00 f$ & $7.00 \mathrm{ef}$ & $5.00 c-e$ & $6.00 c-f$ & $7.12 \mathrm{e}-\mathrm{h}$ & $9.50 \mathrm{de}$ & $13.00 \mathrm{~d}$ & $19.50 \mathrm{~d}$ \\
\hline & Mean & 1.00 & 7.00 & 6.04 & 7.18 & 8.72 & 9.90 & 13.30 & 19.70 \\
\hline \multicolumn{2}{|c|}{ CV (\%) } & 11.23 & 10.65 & 10.23 & 13.00 & 10.49 & 9.63 & 5.80 & 3.71 \\
\hline \multicolumn{2}{|c|}{ LSD $(5 \%)$} & 1.21 & 1.64 & 1.45 & 1.30 & 1.29 & 2.08 & 1.23 & 1.13 \\
\hline
\end{tabular}

DAE = Days after emergence. Means followed by the same letter(s) do not statistically differ at $5 \%$ level tested by DMRT. 
In case of shoot length, it was observed that both at 5, 7 and 10 days after emergence $300 \mathrm{ppm} \mathrm{GA}_{3}$ treated bulbs produced the longest shoot $(16.00 \mathrm{~cm}, 21.00 \mathrm{~cm}$ and $27.00 \mathrm{~cm})$. On the other hand, the shortest shoots $(4.00 \mathrm{~cm}, 6.00 \mathrm{~cm}$ and $10.00 \mathrm{~cm})$ were produced by the bulbs treated with $300 \mathrm{ppm}$ uniconazole (Table 1). Among different growth regulators, uniconazole showed lower performance followed by CCC compared to that of control after 5, 7 and 10 days of emergence. Effect of 2,3,6-TBA was more or less same as that of control. But $\mathrm{GA}_{3}$ showed highest performance for shoot growth (Table 1).

Among the five different doses, highest dose (300 ppm) of $\mathrm{GA}_{3}$ produced longest shoot than the lower ones but highest dose of uniconazole produced shortest shoot followed by CCC after 5,7 and 10 days of emergence and when compared with control. In case of 2,3,6-TBA, it was found that there was no remarkable effect among different doses even after10 days of shoot emergence.

Morphologically uniconazole and $\mathrm{CCC}$ treated roots looked thick and short but $\mathrm{GA}_{3}$ treated roots looked thin compared to that of water treated plants. The CCC induces swollen root tips and it acts on the root meristem to increase cytokinin production, and cause the root tips to swell (Skene, 1970). The reduction of shoot growth resulting from a treatment with a triazole type retardant is accomplished by enhanced pigment content per unit of leaf areas, which is a typical effect of many retardants (Jung et al., 1986). Uniconazole inhibits gibberellin biosynthesis which results in suppression of shoot internodal growth of sugar beet (Dalziel and Lawrence, 1984, Sterrett and Tworkoski, 1987). Swietlik and Miller (1983) observed that plant growth retardant paclobutrazol reduces shoot growth and increases root to leaf ratio and tolerance to water stress. These findings are in accordance with the present results.

Correlation analysis was done to quantify the relationship of different doses of growth regulators with different quantitative characters. Days to root emergence showed the positive and significant correlation with days to shoot emergence $(0.645, P<0.05)$. But root emergence showed negative $(-0.2)$ and non significant correlation with root length. The highly significant and negative correlation was found between days to root emergence and shoot length $(-0.616, P<0.01)$. Days to shoot emergence showed negative but significant correlation $(-0.506, P<0.05)$ with root length. Shoot emergence also showed highly significant but negative correlation $(-0.729, P<0.01)$ with shoot length. The root length showed highly significant and positive correlation $(0.72, P<0.01)$ with shoot length due to treatments with different growth regulators.

\section{Conclusion}

$\mathrm{GA}_{3}$ required minimum days to root and shoot emergence and promote the vegetative growth of onion whereas uniconazole and CCC are retards and 2,3,6-TBA shows a little retarding effect.

\section{References}

Coolbaugh RC, Hamilton R. 1976. Inhibition of ent-Kaurene oxidation and growth by á-cyclopropyl-á-(p-methoxy phenyl)5-pyrimidine methyl alcohol. Plant Physiol 57, 245-248. doi:10.1104/pp.57.2.245

Corgan JN. 1974. Experiences with ethephon on onions. Hort Sc. 9(2), 158.

Dalziel J, Lawrence DK. 1984. Biochemical and biological effects of kaurene oxidase inhibitors, such as paclobutazol. British Plant Growth Regulator Group Monograph 11, 43-57.

Gomez KA, Gomez AA. 1984. Statistical Procedures for Agricultural Research. John Wiley and Sons. Inc., New York, p. 214.

Henry MJ. 1985. Plant growth regulating activity of sterol and gibberellin biosynthesis inhibitors. Plant Growth Regul Soc Am 13, 9-11.

Jung J, Rentzea C, Rademacher W. 1986. Plant growth regulation with triazoles of the dioxanyl type. J. Plant Growth Regul 4, 181-188. doi:10.1007/BF02266956 
Paleg LG. 1965. Physiological effects of gibberellins. Annu Rev Plant Physiol 16, 291-322. doi:10.1146/annurev.pp.16.060165.001451

Rahim MA, Alamgir M. 1995. Effect of paclobutrazol and gibberellic acid on the growth of late planted mukhi kachu (Colocasia esculenta). Progressive Agri 6(1), 39-46.

Skene KGM. 1970. The relationship between the effect of CCC on root growth and cytokinin levels in the bleeding sap of Vitis vinifera L. J Expt Bot 21, 418-431. doi:10.1093/jxb/21.2.418

Sterrett JP, Tworkoski TJ. 1987. Flurprimidol. Plant response, translocation and metabolism. J Amer Soc Hort Sci 112, 341-345.

Swietlik D, Miller SS. 1983. The effect of paclobutrazol on growth and response to water stress of apple seedlings. J Amer Soc Hort Sci 108(6), 1076-1080.

Thomas TH. 1968. The role of growth substances in the regulation of onion bulb dormancy. J Expt Bot 20(2), 124-137.

Ud-deen MM, Hossain T, Molla AH, Hossain MM. 1997. Influence of uniconazole on morphology and gibberellin content in onion. Ann Bangladesh Agri 7(2), 127-131.

Ud-deen MM, Kabir G, Rahman MA, Hossain MS. 2005. Influence of plant growth regulators on morphological changes in onion (Allium cepa L.). Bangladesh J Environ Sc, 11(1), 94-96.

Weaver JR. 1981. Plant Growth Substances in Agriculture. S. Chand \& Co. Ltd., Ram Nagar, New Delhi- 110055, p. 440. 